\title{
PREPARING A TEACHING PORTFOLIO FOR LAW EDUCATORS
}

\author{
PATRICIA WEEKS*
}

\begin{abstract}
AIMS
The aims of this article are to assist teachers of law to begin a process of self-reflection about their teaching, identify areas of strength and begin to develop a teaching profile.

\section{WHAT IS A TEACHING PORTFOLIO AND PROFILE?}

There seems to be some confusion in the literature regarding what a collection of evidence about teaching should be called. In some instances it is referred to as a profile, in others a dossier or portfolio. For simplicity portfolio will be the term used for the collection of data on your teaching. A summary of this information can then be used in conjunction with a curriculum vitae and will be termed a teaching profile.

$$
\text { INTRODUCTION — PLAN }
$$

There are long standing conventions on how to present academic qualifications, research and publications, however, there are few such conventions on presenting information about excellence in teaching.

Throughout the decade there have been calls for greater efficiency and effectiveness in higher education and as in many other areas, teaching performance has come under close scrutiny. No longer, it seems, is it enough to merely assert one's ability to teach. Evidence is now required to support that assertion.
\end{abstract}


Whether you are a lecturer or tutor in law you will be aware of how difficult it is to actually present evidence of your ability to teach.

This article outlines a process to assist you in the preparation of evidence in supporting claims about your teaching ability. Integral to this process is the asking of questions to enable you to critically reflect about what you do when you teach. These questions are only intended as a framework for you to begin keeping evidence and documenting what you are doing or have done.

So that you can become familiar with the process, you are invited now to commence a self-evaluation of your performance.

\section{A SELF-EVALUATION PROCEDURE}

One way to begin preparing a Teaching Portfolio is to commence a process of self-evaluation. While in principle there is no reason why you cannot undertake such reflection alone, in practice it would be beneficial to have a helper in this process. During the self-evaluation process you will be reflecting on your own work. It is useful to discuss your thoughts with a colleague before you make action plans that will help you develop your existing skills.

This reflective procedure will enable you to document your continuous process of improvement in teaching and learning.

\section{Phase 1 - Reflecting}

You can use the topic headings in this article to help you structure your thoughts or use your own criteria. Begin to make a few notes about yourself with respect to your contribution to teaching within your faculty, department, school or institution over the past 5 years; concentrate on the positive aspects.

\section{Phase 2 - Putting your Thoughts into Words: Collaboration, and Observation}

Find a colleague or partner with whom you would like to work, and talk through your thoughts and feelings about your teaching practice. The listener should only listen, ask for clarification and make summaries, but should not make judgements, prescribe or 
advise.

\section{Phase 3 - Action Plans}

You should now be ready to develop your action plans in relation to areas you seek to improve in your teaching. Draw up a list of your intentions, plan a date by which you will complete different phases. Decide who could help you - either a colleague, your students or your peers. You may decide to implement some action research, which is explained later in this article. Whichever method you decide to use, it is hoped that energetic self-evaluation will become a normal part of your teaching routine rather that the exception.

Good teaching involves continuous monitoring of one's own work: observing the effects of instruction on students and responding appropriately. ${ }^{1}$

\section{Phase 4 - Putting It All Together and Making It Work for You}

If you have kept regular data on your teaching in a portfolio, it is much easier when you need to present evidence of your teaching abilities to draw on this information to prepare an accurate profile to be included with your curriculum vitae for a job application, or for tenure or a promotion application.

\section{PHASE 1: QUESTIONS FOR REFLECTION}

These categories are based on work by Gibbs. ${ }^{2}$ They are meant as a guide for your critical reflection. You may prefer to develop your own categories and ask your own questions.

\section{- Students}

Who Are Your Students?

How do you identify any special learning difficulties?

When are you available to your students?

- Content

How do you keep up to date?

Do you read and research in your discipline?

Is the content you teach relevant to student's needs?

Do you regularly update what you teach?

Do you regularly prune out-of-date content? 
Do you belong to an educational special interest group in your discipline?

Are you regularly attending conferences?

Have you formed a network with others in your discipline?

- Educational Aims and Objectives

Which courses do you teach?

What are you trying to achieve in your teaching?

What are the aims and objectives for the courses/subjects you teach?

Have you been involved in initiating, developing or reviewing either new or existing courses?

- Teaching Levels and Methods

How do you teach? What innovations or changes have you introduced?

At what levels have you tutored, demonstrated or lectured?

What steps have you taken to encourage "deep level"8 learning among your students?

What co-ordinating roles have you assumed?

Have you had responsibility for other staff (full or part-time)?

Have you fulfilled any special duties such as co-ordinating practical work or excursions?

Have you supervised Honours, Masters or PhD theses?

Have you acted as a supervisor for field studies?

How do you provide feedback to students regarding their progress?

- Resources

What course materials have you prepared?

What special learning resources have you developed?

What teaching support services do you use?

Have you written any text books?

Do you review new teaching materials and books for possible application?

- External Studies

Are you involved with teaching off-campus?

What materials have you prepared for students?

- Assessment

How do you assess your students? What range of methods do you use and why?

Have you made innovations or changes?

What initiatives have you undertaken?

How do you know your assessment methods are effective?

How do you give feedback to your students on their assessment results?

- Evidence of the Outcomes of Teaching

What have your students learned?

What have they achieved and what have they gone on to do? 
Are you aware of any publications by students on course related work?

Do students succeed in going on to advanced study in your area of specialisation?

\section{- Evaluation Evidence}

How do you monitor and evaluate your classes?

What has this evidence told you about your teaching?

Do you have any unsolicited feedback from colleagues and/or students?

How do you collect feedback from students and peers?

Have you made a videotape of yourself teaching?

Have you maintained a record of the changes you have made resulting from self and student evaluation?

Have you been involved in peer observation?

Have you been involved in any action research?

- Evidence of Continued Study of Teaching and Learning

What am I learning as a teacher?

Have you provided any continuing education programs?

Have you designed, promoted or conducted courses for educationally disadvantaged groups?

What courses have you attended on teaching?

What have you written about teaching?

- Teaching Leadership

What leadership have you shown in improving teaching standards within your own discipline and your institution?

Do you have any evidence of the recognition of your leadership ability, such as the conduct of workshops or seminars for other academic staff?

Have you been invited to be a guest lecturer?

Have you any evidence of help given to colleagues on improving their teaching?

Do you reflect on your teaching practice sensitively?

- Specific Questions for Law Educators to reflect on

Do you give your students an overview of the holistic development of the course?

Do you take time to explain legal terminology as it is encountered?

Do you give students time to copy down names and citations of cases?

Do you provide handouts to ease the note taking in lectures? eg. with references to cases used in lecture.

Do you go further than the legal textbook in lectures?

Do you aim to develop understanding of broader issues of policy, social and professional ethics as well as remembering rules and exceptions?

Have you attempted to teach your students "how" to learn your particular subject?

Are there particular keys to learning torts/contract etc.?

Have you attempted to convey them? 
A Teaching Portfolio is not something you can create overnight. It should be evidence collected over time - a documented history of your teaching excellence and innovation. You need to begin a process of self-evaluation and develop a habit of putting information regularly into a file on you.

\section{And so to begin}

Choose a quiet time and begin to reflect, never miss an opportunity to write down the things that happen during the course of your day and keep asking "why" and "how" certain things happen.

\section{PHASE 2: PUTTING YOUR THOUGHTS INTO WORDS}

There are a few ideas in the following section to help you to begin this process of self-evaluation.

- You may wish to begin keeping a Teaching $\log ^{3}$ to record the patterns in the way you teach and the events that occur. This is essentially a written record of the events of the course you are teaching.

- Action Research ${ }^{4}$ is a cyclical process of observing what happens in your teaching and reflecting on those observations, finding explanations and planning improvements. There are a variety of other ways to evaluate your teaching. A simple check list $^{5}$ of Did I Do? . . . will help you to structure your thoughts about quality teaching.

- You may wish to invite another teacher into your classroom to observe what happens and to be your "second pair of eyes". You can then reflect on the data collected from this process to see what you are doing and compare it with what you think you did. ${ }^{6}$ Why not begin keeping a reflective diary ${ }^{7}$ or journal, develop a questioning approach to your teaching, asking yourself:

- what do I do that causes learning to occur?

- what am I doing to assist my students to learn?

- what do I hope my students will learn from me?

If you are hoping to develop your students' abilities to become creative, flexible critical thinkers, and to increase their desire to become self-directed lifelong learners, then it would be interesting to know what you, as the teacher are doing to promote those skills 
in your classes. How closely related are the learning tasks in your classroom to the learning outcomes?

By reflecting on these issues you will begin to collect a portfolio of evidence about what you have done in the past (don't go back too far - this is not just a history book), what you are doing now and how you intend to improve in the future. This is your document, no one else need ever see what you write in your portfolio. You will draw on certain items from your portfolio to present evidence of your teaching abilities when it is required, but your portfolio is yours.

There are many styles to choose from for writing or compiling a portfolio. You may choose to keep all your information on a wordprocessor, others will prefer to keep a file, you may keep your information in a manual, in a "portafile", or a shoebox, under the house or in a drawer, beside your bed or in your office - the choice is yours. There is no "right" way or correct answer, as this is a personal document. Your portfolio will then be ready one day in the future, for you to take the relevant items and compile them into a document about you, for whatever purpose you desire.

\section{PHASE 3: ACTION PLANS}

Take this opportunity to begin, don't procrastinate — start now. Start collecting evidence on your teaching, start researching your teaching.

What do you propose to do as a result of this self evaluation process?

- about developing a teaching portfolio

- about creating a teaching profile

- as a teacher to improve student learning

- about your subject and about education in general

- about being more creative in your teaching and enhancing the learning environment for your students

- about continuing your own personal and professional development

- about encouraging “deep level” learning by your students

- about helping others in the institution or in your discipline to improve their teaching 


\section{PHASE 4: PREPARING A TEACHING PROFILE}

According to Gibbs, ${ }^{9}$ a teaching profile is a document you create which pulls together evidence about your competence as a teacher. It is used to present an overall picture of your teaching to others in a concise and convincing way.

It is important that this document be succinct, as you need to make an impact. It should normally be no more than 3 pages long, which is a reasonable amount to ask someone else to read. It is important that you accurately convey the scope and quality of your teaching.

You need to be selective about what you include in your profile so choose items which highlight your strengths and achievements and if necessary refer the reader to an appendix for more information.

It is important that your document describes you. It will be unique, as you are, so choose wisely and select items for your profile according.

When presenting any application, it is wise to pay attention to local criteria. Check the duty and qualifications statement for the position before compiling your application, and finally make certain that you present your application professionally — this document will represent YOU. The following ideas are offered as a selection of the sort of information you could give as evidence to support your assertion of teaching quality.

\section{IDEAS TO HELP YOU CREATE YOUR TEACHING PROFILE}

- Personal details

- Personal teaching philosophy

- Qualification

- Summary of service (last five years)

- Teaching experience (levels)

- Teaching expertise and accomplishments

- Teaching innovations or changes

- Publications related to teaching

- Papers presented at conferences to do with teaching/ learning

- Course design

- Teaching evaluations 
- Awards for distinguished teaching

- Grants received for teaching development or innovation

- Teaching leadership and administration

- Membership of teaching related associations

- Contribution to improvement of teaching

- Research related to teaching

- Teaching experience elsewhere

\section{FURTHER READING}

Gibbs G 53 Interesting ways to appraise your teaching (Bristol: Technical and Educational Services, 1989).

Gibbs G Creating a teaching profile (Bristol: Technical and Educational Services Ltd, 1989).

Holly ML Keeping a personal-professional journal (Geelong: Deakin University Press, 1984).

Kemmis S \& McTaggart R The action research planner (3rd ed) (Geelong: Deakin University Press, 1988).

Newble D \& Cannon R, A Handbook for teachers in universities and colleges: A guide to improving teaching methods (London: Kogan Page, 1989).

Prosser A, Promotion through teaching (1980) HERDSA News (2)2. 8-10

Ramsden P \& Dodds A, Improving teaching and courses: A guide to evaluation (Melbourne: University of Melbourne, Centre for the Study of Higher Education, 1989).

Ramsden P, Studying learning: Improving teaching. In P Ramsden (ed) Improving learning: New Perspectives (London: Kogan Page, 1988).

Roe E, How to compile a teaching portfolio: A FAUSA guide (South Melbourne: Federated Australian University Staff Association, 1987).

Ruddick J, Teaching as an art: Teacher research and research based teacher education (Second Annual Lawrence Stenhouse Memorial Lecture, University of East Anglia, 1984).

Schon DA, Education the reflective practitioner: Towards a new design of teaching and learning in the professions (San Francisco: Jossey-Bass, 1987).

Seldin $\mathrm{P}$, The teaching portfolio: A practical guide to improved 
performance and promotion/tenure decisions (Boston: Anker Publishing Co. Inc. , 1991).

Sobel MA \& Maletsky EM, Teaching mathematics: A sourcebook of aids, activities and strategies (2nd ed) (New Jersey: Prentice Hall, 1988).

Smyth WJ, Reflections in action. (Geelong: Deakin University Press, 1986).

Smyth WJ, Clinical supervision: Collaborative learning about teaching (Geelong: Deakin University Press, 1984).

* Academic Staff Development Unit Queensland University of Technology. I gratefully acknowledge the assistance of Ms Carol Nicoll, Senior Research Assistant, Academic Staff Development Unit at the Queensland University of Technology, for her help in compiling the questions in this article specifically dated to law education.

(c) 1992. (1992) 3 Legal Educ Review 295.

1 P Ramsden \& A Dodds Improving Teaching and Courses: A Guide to Evaluation (Melbourne: University of Melbourne, Centre for the Study of Higher Education, 1989), at 33.

2 G Gibbs, Creating a Teaching Portfolio (Bristol: Technical and Educational Services Ltd., 1989).

3 Ramsden \& Dodds supra note 1.

4 S Kemmis \& R McTaggart The Action Research Planner 3rd ed (Geelong: Deakin University Press, 1988).

5 Ramsden \& Dodds supra note 1.

6 WJ Smyth Clinical supervision: Collaborative learning about teaching (Geelong: Deakin University Press, 1984).

7 ML Holly, Keeping a Personal-Professional Journal (Geelong. Deakin University Press, 1984).

8 JB Biggs \& R Telfer The Process of Learning (2nd ed) (Sydney: Prentice Hall, 1987), at 149.

9 Gibbs, supra note 2, at 9. 